\title{
Characteristic features of tribal groups Mongun- Tayginsky district of the republic of Tyva
}

\begin{abstract}
Introduction: The article deals with the history of tribal groups Tuvan, their resettlement, as well as the example of Tuvan delivery Salchak, Dongak, Irgit Khertek and discussed the current situation. The purpose of the article is the study of tribal groups Salchak, Irgit, Dongak, Khertek as the tribal composition Mongyn-Taiga kozhuun Republic of Tuva with historical and ethnographic point of view, at the present stage. Location Tuva in the geographical center of the Asian continent left its imprint on her relationship with the inhabitants of neighboring and nearby regions, as well as in the tribal structure. Compared with the central kozhuuns Tuva territory Mongun-Taiga was sparsely populated. The population increased as the migration of peoples from neighboring territories. Important factors movement of some portion of the population of neighboring areas in Taegu-Mongun are the following:

1. An increase in family relationships and creating marriage;

2. A severe feudal oppression, arbitrary Mongolian officials, torture and sentence;

3. Immigration policy Qin authorities-bogdyhana, then zapadnomongolskih feudal lords, who on their own are often resettled certain Tuvan groups in different places;

4. Natural disasters (crop failures from jute);

5. The labor market situation in kozhuun.
\end{abstract}

Population Mongun-Tayginsky District represented by the following tribal groups: the largest in size-Irgit, Salchak, Dongak, Khertek; great in number-Saaya, Khomushku, Oorzhak, Kara-Sal, Kuzhuget, Mongush, Kuular, Ondar; small in number-Kyrgys, Sat, Oyun, Tulush, Count.

Results: Territory Mongun-Tayginsky District was the area of the tide of different population groups. Distance from the neighboring kozhuuns not mean complete isolation. Tuva has been involved in a circle of many historical events that took place in the eastern part of Central Asia. The local population mastered mountain ranges, long knew most accessible passes, used bed many rivers as a route for their movement.

Compared with the central kozhuuns Tuva territory Mongun-Tayginsky District was sparsely populated. The population increased as the migration of peoples from neighboring territories.

Conclusion:Thus, for the first time collected materials on the history and modernity of these tribal groups Mongun-Tayginsky District of the Republic of Tyva how Salchak, Irgit, Dongak and Khertek. Author prepared in the course of the survey table ethnosociological composition tribal groups Mongun-Tayginsky District, which, undoubtedly, is a novelty.
Volume 5 Issue I - 2020

\section{Ayyzhy Elena Valerevna}

Associate Professor, Federal State Budgetary Educational

Institution of Higher Education, Tuvan State University, Russia

Correspondence: Aiyzhy Elena Valerevna, Federal State Budgetary Educational Institution of Higher Education, Tuvan State University, Russia, Email aiyg@mail.ru

Received: January 23, 2020 | Published: February 13, 2020

Keywords: republic of tyva, mongun-tayginsky district, salchak, irgit, dongak, khertek, tribal group, the turko-mongolian world, tuva

Tuva-titular ethnic group of the Republic of Tyva (Tuva), located in the geophysical center of the Asian continent-in the upper basin of the great Siberian river Yenisei and has a total area of about 175.5 thousand Km. Tuva-one of the ancient Turkic-speaking peoples of Central Asia and the Sayano-Altai mountains. The modern name of the Tuvan people "Tyva", "Tuva Kizhi" is mentioned in the annals of the Sui (581-618.) And Tang (618-907.) Dynasties of China in the form of Dubo, tubo that with respect to some of the tribes living in the upper reaches of the Yenisei River and Hovsgol lake area. ${ }^{1}$ About nearest historical ancestors of modern Tuvan "chikah and Ahaz"-there

${ }^{1}$ History of Tuva. T. 1-2. - M .: Nauka, 1964. is information in the runic monuments of ancient Turkic runic script (VII-XII centuries.). In Mongolian, Arab-Persian sources XIII-XIV centuries. also contains information about Tuva and its inhabitants. Anthropological type Tuva belong to Mongoloid Central Asian type North Asian race. Eastern Tuva-Todzhins-are a special type with a dash of Central Asian component. KA Bicheldei in his work "The sound system of the dialects of Tuvan language" (2001) writes that the Tuvan language as an independent language formed the beginning of the tenth century. ${ }^{2}$ However, today it is noted specificity of individual

${ }^{2}$ Bicheldei KA. Sound system dialects of Tuvan language. Moscow. 2001. 89 p. 
linguistic groups. In particular, in the Tuvan language has four dialects: western, eastern, central and south-east. ${ }^{3}$

Location Tuva in the geographical center of the Asian continent left its imprint on her relationship with the inhabitants of neighboring and nearby regions, as well as in the tribal structure. In particular, it was periphery powerful power valiant Hsiung (II BC-I in AD.....), Part of the early medieval superetnopoliticheskih States: Old Turk (VIVIII cc.) Uygur (VIII-IX cc .) Drevnekyrgyzskogo (IX-XII centuries.) and Mongol Empire Kaganates Genghisides (XIII-XIV centuries.) Central Asia. ${ }^{4}$ These powerful early feudal state played a prominent role in the history of nomadic civilization and ethno-political situation in Central Asia and the Sayano-Altai region. No less important was the Great Migration: Xiongnu, Turks, Mongols from deep steppes of Central Asia to Europe. Under the influence of these historical events occurred deep socio-economic, ethnic and cultural processes in the Sayano-Altai region, including the territory of modern Tuva. They had a definite impact on the consolidation of Tuvan tribes and, ultimately, their formation into a single ethnic group. It should be noted that the prevalence of physical type of local residents Mongoloid features researchers have linked it with the period of the invasion of Tuva in III. BC. e. Central valiant tribes related Huns (Hsiung). ${ }^{5}$ At the end of XIII-XIV centuries. the ethnic composition of the population of Tuva is already included in the main groups who took part in the formation of the Tuvan people-descendants of Turks tugyu, Uighurs, Kyrgyz, Mongols, and the Samoyed and Ket-speaking tribes. ${ }^{6}$ In the XVI-XVII centuries. Tuva tribes entered the Central Asian state Altyn-khans. From the middle of the XVIII century. Manchu (Qing) dynasty of China subjugated and the population of Tuva, which was divided into several administrative units-khoshuns (kozhuuns). ${ }^{7}$ They ruled the hereditary Tuvan "princes"-noyons. Tuva were also part of a number of other small khoshuns managed Mongol princes, both in Tuva and in Mongolia, including the Mongolian Altai. Each khoshun divided into smaller administrative units-sumony, and those in turn-on the Arba (desyatidvorki). ${ }^{8}$ By the beginning of XX century. Tuva was nine khoshuns.

A single administration of Tuva, in no small measure contributed to the consolidation of Tuvan in a single nation, the formation of self-awareness and self-obscheetnicheskogo. It was in the era of stay Tuva tribes as part of Manchu China at the end of XVIII-XIX century. end formation Tuvan ethnic group. One of the important factors in this process was the establishment of the administrative division, mainly based on a generic way, and on the territorial principle, which contributed to the blurring of the tribal differences. Sub-ethnic group of Tuvan residents were Sayan-eastern Tuva-Todzhins. ${ }^{9}$ Common ethnic self Tuvan "Tuva-Kizhi" finally happened to the beginning of the XIX century. in the process of consolidation into a single ethnic group. In 1911-1913 gg. China's Xinhai Revolution took place as a result of which was overthrown by the Manchu Qing Dynasty. After

${ }^{3}$ Bicheldei KA. Sound system dialects of Tuvan language. 2001.90 p.

${ }^{4}$ Mandi MK. Historical and geographical features of the formation of the Tuvan people. $2015 ;(4): 225-257$.

${ }^{5}$ Anayban ZV. Mannai-ool MH Origin Tuvan. Background//New Research of Tuva. 2013;(3). Tuva yesterday, today and tomorrow.

${ }^{6}$ Turkic peoples of Eastern Siberia/comp. In: DA Funk, Holes Ed, DA Funk, NA Alekseev M, editors. Nauka; 2008. 23 p.

${ }^{7}$ Anayban ZV. Mannai-ool MH Origin Tuvan. Background//New Research of Tuva. 2013;(3)

${ }^{8}$ History of Tuva. Nauka. 1964. 218 p. T. 1-2.

${ }^{9}$ Weinstein SI. Tozhu tuvans. Historical-ethnographic essays. Nauka. 1961. p. $135-137$. that, the mass demonstrations against the Chinese administration and foreign entrepreneurs started in Tuva. At the same time, tsarist Russia Tuva becomes the object of colonization and economic development. The Russian government, relying on moved in the second half of the XIX century. Russian peasants and industrialists, seeks to subordinate it to Russian interests. As a result, April 18, 1914 signed a government decree on the adoption Uryankhay Territory (formerly known as Tuva) under the protectorate of Russia. ${ }^{10}$ kinship terms are widely studied by scientists, in addition, in many works of fiction and Tuvan folklore, in particular, in the epic and proverbs are represented.

Nomadic heritage and the traditional tribal structure of society one way or another, put Tuvinians going to have to share with each other. They still define themselves as belonging to one of the divisions ethnolocal-tyvalary Tandy (Tuva Tuva itself), HSI tyvalary (Tuva Mongolia) and kydat tyvalary (China Tuva). This is followed by division of the administrative basis-mec-Khemsky, ulug-Khemsky, Pius-Khemsky, Barun-Khemchiksky, Dzun-Khemchiksky, MongunTaiginsky, d-Khol, Chaa-Khol, bei Taiginsky, Erzinsky, Todzha, Ovyurskogo etc. .d. Accordingly tsengelskie, Khubsugul, kobdinskie Tuva live in Mongolia, hanasovskie, Komsky, habaskie-in China. The stability of the tribal identity, first of all, indicates that each person is perceived as a member of a particular kind, the carrier of his typical traits of collective attitudes and values. Rhode designated certain symbols-markers-a clan territory, including the ancestral village, hunting and grazing lands, sacred mountains, rivers, springs, trees and patron spirits that protect it, and this ancestral shamans Tanmaancestral property signs on cattle, signs-printing of the authorities. ${ }^{11}$ Special names for each of different types of Tuvan are the source of the information needed for a deep knowledge of its history. Previously, Tuva did not say the name of the mother, not the father's name was called, and pointed to the name of the sister group to which he belonged. Let's say, two strangers met on the way. Elder asks, "Whose son are you?" Or "Whose daughter are you?" Answer: "Son Mongush Chambala" or "Daughter Saryglar Chechek".

Here are the names of tribal or tribal groups Tuvan: Ak AdygTulush, Mongush, Ak-Mongush, Kara Mongush, Bai-Kara, Baraan, Dagat, Dolaan, Dongak, Kara Dongak, Saryg-Dongak, Kara-Sal, Irgit, Kuular, Kzhuget, Kyrgys, Number, Maadi, Ondar, Oyun, Oolet, Saaya, Sartyyl, Sarygar, Sat Soyan, Tumat, Khertek, Khovalyg, Khomushku, Hoyluk, Choodu, Shalyk, Oorzhak. Be sure and it was necessary to learn about the people related groups, about where they live and to which kozhuuns belong. People of the same kind of large distinction sometimes each other, calling himself the place of residence, for example, Dongak, Chaatinskie Dongak, Chirgakinskie Dongak and so on. D. In Tuvan there is a saying: "Instead of death, name, ie credit, better off dead man himself..." For a long time Tuva with special attention to the person's name. Each infant was given a special, the most appropriate his name. When children begin to understand something, the parents told them in detail about the names of all his relatives, but were taught to children at any age is not directly called names of parents, relatives, respectable people because of respect for him. In this case, instead of real names pointed to substitute their names respectful, taught the children respectfully refer to elders. The ancestors said that the name of the person-himself. Name is closely linked to his moral character, love, pride, kindness,

${ }^{10}$ Lamin VA. History of Tuva $3 \mathrm{t}$-. T. II/Pod Society. Novosibirsk: Nauka; 2007. 430 p.

${ }^{11}$ Kurbatsky. GNTuva in its folklore (historical and ethnographic aspects of Tuvan folklore). Kyzyl: Tuva book Publishing House; 2001. p. 191-192. 
impatience, bad reputation, so Tuva, first of all, think about the purity of his name, which was one of the best traditions of our ancestors. Always think about the purity of his name and honor-the covenant of our ancestors to all subsequent generations. ${ }^{12}$

The surviving manuscripts of unknown Tuvan author of "History of previous noyons Tuvan people" to Tuvan treated Oyunarsky, Salchaksky, Todzha, Hasutsky, Khemchiksky (Yeah) khoshuns and to the Mongolian-Beezi, Maadi-Choodu (Daavan). Shalyk-sartuul (Nibazy) khoshuns. Each khoshun owned by the Manchu emperor, ruled by hereditary rulers-noyons approved in the position of the Qing authorities. ${ }^{13}$ Qing government took place in Tuva administrativeterritorial reform, preserved until the present day. Thus, Tuva during his stay under the rule of the Manchu-Chinese authorities have experienced cruel forms of management of the strict laws of the Qing Empire (in particular, the "Law Code of China Chamber of External Relations") and the heavy exploitation in the form of tax (ALBA) to the total population. The treasury of the Manchu Emperor Tuva annually paid 9000 high quality sable furs or other equivalent in much larger quantities. Nevertheless, the great Chinese civilization has had some positive impact on the semi-colonial Tuva and its people, in particular in the traditional folk culture and art. It is an administrative and territorial reform based not on the principle of the tribal settlement, and territorial. Such unified management under the auspices of Tuva ambyn-noyonstva with the rate of (capital) Samagaltay in the southeastern part of Tuva Tuvan contributed to the consolidation of a single ethnic group. Capital (Samagaltay) was not only the administrative and religious center of Tuva: economic, commercial, religious, and international relations, too, went through it. ${ }^{14}$ Now pay attention to our main topic of the article to the generic groups Mongun-Tayginsky District of the Republic of Tyva.

\section{Salchak tribal group}

Many modern scholars as the LV Grebnev, LP Potapov et al. Believe Tuvan tribe Salchak originating from saldzhiutov which Rashid alDin are indigenous Mongols. For the first time this assumption was expressed GE Grum Grzhimailo, who wrote: "Saldzhak is probably one of the variants Rashid al-dinovskogo saldzhiut....". ${ }^{15}$ VY Vladimirtsov Saldzhiut classifies as to the Mongols. ${ }^{16}$

Here is the version of Mongolian origin Salchak. ${ }^{17}$ Tuvinian tribal group Dongak Salchak and back to dunkaitam (Tuncay, Donghai) and saldzhiutam Rashid al-Din and "Secret Legends". As part of the terms and Duncan saldzhiut final $t$ is the plural of fundamental principles and Dunham saldzhi their Mongolian design. In Tuvan is this fundamental principle exists in another design: salcha dong + and the word of the Criminal Code, in which case these terms may be disclosed as "clan, tribe or generation salcha, dong". ${ }^{18}$

Saldzhiuty based on reports Rashid al-Din and the "Secret

${ }^{12}$ Kenin Lopsan. MBTyva chonnuts Burung uzhurlary [Ancient ethics Tuvan people]. Kyzyl: News Tuva; 1994. p. 53-61.

${ }^{13}$ Okladnikova EA, Popov VA. Kinship names in the function of sex and age appellatives in modern Russian society (the psychological aspect). Algebra kinship: Kinship. Kinship systems. System of kinship terms. Science of RAS; 2000;5:243-258.

${ }^{14}$ Potapov LP. Materials on the ethnography of Tuvan districts Mongun-Taiga and Kara-Khol. Proceedings of Tuva complex archaeological and ethnographic expedition of 1957-1959 years. TI Science-AM. 1960. p. 171-248.

${ }^{15}$ Serdoba NA. The history of the Tuvan nation. Kyzyl. 1970. p. 178.

${ }^{16}$ Weinstein SI Essay ethnogeny Tuvinians. UZTNIIYALI. Vol. 14. S. 191

${ }^{17}$ Serdoba NA. The history of the Tuvan nation. Kyzyl. 1970. p.178.

${ }^{18}$ Ibid. $172 \mathrm{C}$
History" of the origin of their Saldzhi, the son of the mythical progenitor of the Mongols, Alan-Goa, considered Mongol tribe. At the end of the XII century, they "lived on the lower reaches of the river", from the confluence of the river which forms the AnkaraMoron. ${ }^{19}$ In 1201 saldzhiuty and other tribes antichingis the Hahncoalition "pokochevali downstream river. Ezine and committed ritual erection Chhamuhi in Gur-khans on top of wooded mountains at the confluence of the river Erizne Kanmuren ". From there they marched against Genghis Khan. In turn, Genghis Khan and Wang Khan (It Khan by Rashid al-Din), speaking with Onon (by Rashid al-Din), continued its advance downstream river. Kerulen in Lake District. Buir-nor (on the border of Mongolia and Barga), where there was a fierce battle. He was referring to Khan, Temujin says about this event: "Once again, I turned into a broad-falcon, flew across Kule-Nauru and caught seronogih herons and given to you [of you]. If you ask: "Who are they"-The tribe katakin, saldzhiut and Duncan "(?). ${ }^{20}$

\section{Kule-Naur Form}

The lake Dalai-nor, to the north of Buir-nor. Broken Genghis Khan and Khan He tribes fled to the Southern Altai, Selenga, Onon. Saldzhiutov tribes fleeing from Naiman, appeared in the foothills of the Mongolian Altai in the Ulug-Taha, but overtaken and here Genghis Khan, crossed the Altai and escaped downstream Hushmigirskoy Urungu River, Lake District. Kishil-bali-Naur Form (Lake Ulyungur). Thus, saldzhiuty nomadic earlier in northeastern Mongolia in 1202 has roamed the west Mongolia Urungu River area and Lake Ulyungur. ${ }^{21}$ In 1204, Genghis Khan "marched on the Naiman people. Naiman at that time were between Altai and Khangai. By Naiman among other tribes joined saldzhiuty. Genghis Khan defeated Naiman, joined by tribes "in the Altai Halfhill,-stated in the source-our people have taken away all the Naiman, who was in a state of complete disorder. Immediately surrendered to us and to all who were with Chzhamuhoy: chzhadarantsy, hatagintsy, salchzhiuty, Dorbe, taychiudtsy and ungirat" 22

Saldzhiuty in spite of the incessant struggle to Genghis Khan for a few years and the constant defeats inflicted by them, while maintaining their independence. Continuing then, after the conquest of Genghis Khan areas of Central Asia, living on a limited area, saldzhiuty proven to be one of the most numerous Tuvan tribes mastered the Turkish language..$^{23}$

LR Kyzlasov ${ }^{24}$ also agrees with the LV Ridge, that part of the Mongol tribe saldzhiut (along with the Duncan and manghud) became part of the Tuvan, retaining its name in Turkish name registration as a modern tribal groups Salchak. Thus, we can assume that in the ethnogenesis Tuvinians took pieces of a broken Genghis Khan tribe saldzhiut. ${ }^{25}$ However, in the literature, this version is still full approval is not received. As is known, Tuva, Salchak call themselves, were part of the same name khoshun in which one of the four was called sumonov Salchak. However, F. Kohn noted in this sumone part of oleth, Irgit, Soyan and others. Ethnonym Salchak preserved in modern Tuvan. This and some other circumstances raise doubts

\section{${ }^{19}$ Ibid. S. 174}

${ }^{20}$ Serdoba NA. The history of the Tuvan nation. 1970. p. 174. Rashid - ad-Din Collection of Histories.

${ }^{21}$ Ibid.

${ }^{22}$ Grebnev AV. The population of Tuva to the XIII century. Ultrasound TNIIYaLI. 8:166-168.

${ }^{23}$ Ibid. S. 182

${ }^{24}$ Kyzlasov LR. Tuva in the Middle Ages. 1969. p. 168.

${ }^{25}$ Weinstein SI Essay ethnogeny Tuvan UZ TNIIYaLI Vol. 8. - P. 191. 
as to the lawfulness of attributing to the Mongolian Tuvan Salchaks saldzhiutam as group Irgit Soyan and origin are not Mongolian. ${ }^{26}$

There are other versions of the origin of Salchak. In particular, the origin Salchaks associated with chikami. ${ }^{27}$ That, it seems quite likely. Some of the information we find in EK Yakovlev, so the name Salchak bones allegedly produces the word "beardless" (beardless), ${ }^{28}$ Ie byTuvan "fats choke" or "Sala choke." With this, of course, associated with going to the people saying "salchaktarnyn Salah choke", ie "Salchaks have no mustaches, beards". By the end of XIX- beginning of XX century. most of the tribal groups living in the lower reaches of Salchak Kaa-Khem, rivers Buren and Ulug-Khem. ${ }^{29}$

According LP 1958 Potapova Salchak lived on the farm in Malchyn Mongun-Taiga and employs 178 people, about 100 people lived in the region of Kara-Khol. ${ }^{30}$ Currently in tribal group Salchak Mongun-Taiginsky kozhuun according village councils most rural communities tribal group Salchak reside in sumone Kargynskom (156) and Mogun-Burenskom (443). The names of Salchak found in 555 cases, in 140 cases, patronymic, and 24 names (Table 1).

Currently Salchak spend rite ovaa dagyyry near river Mugur. ${ }^{31}$ Praying ovaa dagyyr held annually as before.

In general, the studied tribal groups, as well as Tuvinians generally were common prayers with certain requests to the sacred mountain. In Mongun-Taiga prayers on the sacred mountain often occurs without the participation of the Shaman (they led the Ancient Murrelet). Residents of the lower reaches of the river. Kargy worshiped before (as a sacred) Mount Ak-Pashto. This does not let the cattle, and even the people, especially women, reluctantly admitted to it. According to Tuvan Tongak, as a child she had been to Tuvan aalah located behind the ridge saadak, near Kargy valley in the upper river. Tholey. The inhabitants of these villages arranged while their mountain of prayer in the upper Tholey from the famous source there (Arjan) arising out of the ground near the place where there were five larches. While these larch were very young. During prayers on larches hung colored ribbons. It does not suit either ovaa or initiation of any pet. Elderly (or shaman) simply refers to the mountains with a request for a prosperous life, sprinkled them Araki water from Arjan and burning juniper. But in addition to such supplication residents in the upper reaches of Tholey suited also praying about ovaa where dedicated to the spirits of the mountains of individual pets.

Especially tell about the prayers associated with the device ovaa mountain and dedication in ydyk consecration of pets, mainly domestic bull (also called ydyk pets, dedicated to the spirits of the mountains). The fact that in Western Tuva ydyk devoted most of the bull, can not go unnoticed, especially when compared to custom the Altai and Khakassia, who initiated into ydyk mainly horses (the cult of their dedication, not only was strongly developed, but also developed to the last detail, to the extent that one or inoi mountain dedicated to the horse only a particular suit). Marked specificity ydyk cult Tuvinians explained by the extensive use here as a transport animal bull. Since the main purpose of initiation ydyk was, above

\footnotetext{
${ }^{26}$ Serdoba NA. History of the formation. p. 127.

${ }^{27}$ Khertek LA. Abaev Historical Tuvinians memory ethnonyms and oynonimah. Head. 1999;5-6.

${ }^{28}$ Serdoba NA. History of the formation. p. 179.

${ }^{29}$ Flood LP. Sketches of Tuvan folk life. Nauka; 1969. p. 358

${ }^{30}$ Ibid. S. 358

${ }^{31}$ Informant Dongak Anai-Khaak Kyzyl-oolovna resident Mongun Taiga with Mugur-Aksy, ul. Eric 24, was born with. Mugur-Aksy, born in 1974 profession of kindergarten teacher DOW "The Scarlet Flower" (Date: 04/02/2017).
}

all, the preservation and well-being of the flock, and first of all those species of domestic animals, which belongs to, it is easy to understand why the preferred ydyk-bull. The bull was dedicated to all the spirits of the mountains, rather than a specific grief and called ovaa ydyk most as a rite of passage was called "ydyk kylyr" (literally, "to make ydyk"). Residents of the upper river. Kargy dedicated white bull red head (it was possible to devote a white bull with red ears), and the inhabitants of the lower reaches of the river, "put" white bull with black eyes. Chose necessarily castrated bull (balls) and dedicated it to the owner of the entire mountain aal (to the inhabitants of this village live well and safely). Two-ydyk bulls (from residents upstream and downstream) placed in the common ovaa, but at different times. Ovaa was on the hill at the lake. Ak-Khol 'and was called the same area.

This resulted annually dedicated-ydyk bull, which was purified (as well as the first time, at initiation mountain host), it changed the tape and released again to the fold. When the bull-ydyk getting old, then dedicated the new and old washed Arzhanov, also with the help of juniper beam and slaughtered for meat. Skin with ydyk removed so that the bones of the legs (to the knees) and a skull remained neobodrannymi. As such, the skin of a bull hung on poles, as far as possible put to the tree near aal, where he lived the owner of the herd, which went ydyk. Its flesh eaten all residents aal together, and the bones buried in the ground near the exposed skin. Caring about how to choose the appropriate new ydyk, he was assigned to the same host, in which the herd was grazing aged ydyk. If this did not turn out aale bull suitable suit, it picked up in another aale, whose inhabitants engaged in prayer and dedication to the general ydyk. The owner of the bull selected for initiation, did not carry the material damage, as after praying the bull, now ydyk, returning to his former flock. As already noted, along with the collective dedication ydyk bull in Mongun taygintsev practiced and personal dedication, which was called Morgul kylyr (tayylgan-the eternal gift of the wooded mountains). This requires some explanation. Under tayylganom here it means praying with hanging animal skins, dedicated to the mountain master. This name apparently was because the individual dedication bull-ydyk characterized in that the post-mortem ydyk his skin hung about ovaa. Individual dedication bull doing some more or less wealthy masters, in order to provide family wealth and prosperity. But often such dedication ydyk cause severe long-term illness of the owner or any of his family chlenoz. In this case, the host invited a shaman or a llama and consulted on the matter. As a shaman,

Having decided to devote the bull, the host announced it to relatives and neighbors. This supplication (tagyr) drove all who only learned about it, no matter, where one lived. Each carrying with him Araki cold cooked lamb, cheese, and so different. D. In this case the initiation selects a suitable place on a mount (since ydyk devoted mountain host) and here was arranged ovaa. Individual-ordination ydyk bull could be done on the old public ovaa. Dedicated ydyk in this case, exactly the same as it did when the dedicated or publiccollective ydyk, as mentioned above. However, when you change the owner of his individual ydyk bull was supposed to be slaughtered near the old ydyk ovaa, cook it and eat meat until the last piece on this site to all those present, the skin of the old ydyk hang on a pole, Residents upstream river. Kargy and the upper reaches of its right inflow Mugur doing general ovaa on Mount Mongun Taiga. ${ }^{32}$

Thus, from the research it has been identified different versions of the origin of the genus Salchak, for example, scientists LV Grebnev, LP Potapov, GE Grum-Grzhimailo LR Kyzlasov et al. Believe Tuvan

${ }^{32}$ Potapov LP. Sketches of Tuvan folk life. Nauka; 1969. p. 359. 
tribe descended from Mongolian Salchak saldzhiutov, and that is what the broken shards of Genghis Khan tribe saldzhiut. Khertek L. and A. Abaev tend to other versions, namely the origin of Salchaks chikami associated with that, it seems quite likely. Thus, currently in tribal group Salchak Mongun-Taiginsky kozhuun reside in sumone Kargynskom and Mogun-Burenskom.

\section{Tribal group Irgit}

Irgit tribal group is among the largest groups of Tuvan ethnos. The history of the ethnonym indicates the presence of the alien component and mixed constituent ethnic elements. Tribal group Irgit prevalent not only in Tuvan, but also in the Altai (Tuvan Irgit Altai call themselves hoyukami. Since time immemorial among the people wandering along the rivers $\mathrm{Ob}$, Irtysh, Yenisei and Lena lived nomadic Hun-Sarmatian, the Finno-Ugric peoples, the Persians and Turks. Among these tribes has its own ancient roots born Uighur mergity. Calling themselves Hoyuki, thereby emphasizing that they belong to the Central Asian Uighurs "Guyuk." According to the rule of money-grubbing Turkic peoples standing in front of a phoneme " $\mathrm{m}$ " disappears, and on mergity not binding and $\operatorname{Irgit}^{33}$ ), Partly at Khakases (Irgit considered at Khakases descendants Kyrgyz previously lived and is currently in the upper reaches of the White Yus and p. Uibat ${ }^{34}$ ) Buriats (so-called Tunkinskoye Soyot currently Okinsky khoshun Tunkinsky aimak ${ }^{35}$ ) Yakut (Kangalassy Yakut Нанаlas located on the left bank of the Lena River, $45 \mathrm{~km}$ north of Yakutsk center. Kangalassky ergity were among the "foot" Saha Vilyuya identified with Irgit among the Sayan-Yenisei peoples. It is characteristic that Irgit considered Turkified Samoyeds at the same time, they were the first Turks in the Sayano-Yenisei region $^{36}$ ), Even khotogoid (Irhit) and western Mongols (Irgit were mainly from Oirats formed in the 1630s Four Oirat). ${ }^{37}$

Tunkinskoye Soyots live in Buryatia Tunka valley and are the descendants of Tuvan-Irgit XVII-XVIII centuries. In the Russian written sources of the XVII century. Irkit mentioned at the beginning of the 60 s among the tributaries of the population Kaysotskoy piece of land of more tributaries payers in the amount of about 400 people. ${ }^{38}$ Irkit constituted a majority, living in the territory, part of the Irkutsk district. Some of them lived on the river Irkut, whose name may have derived from the group Irkit. These Tuva-Irgit paid tribute to Tunkinsky fort back in 1735 and were considered subjects to the Russian state. ${ }^{39}$ MA Castren in 1848 in Irkutsk, near Lake Valley. Tunka also met Irgit previously roamed in the Nizhneudinsk district in the mountains on the Oka River (a tributary of the Angara River), where the remainder of their relatives. Irgit were intermediaries in the exchange trade between the Buryats and other Tuvan tribes. ${ }^{40}$ In the western part of Tuva, also lived a large group Irgit whose nomadic, in all likelihood, extend to the Southern Altai, because of the separation of the border with Russia, after the occupation of Tuva, the Manchu

${ }^{33}$ Soyots, Potapov LP. Ethnic composition and origin of the Altai. Leningrad: Nauka; 1969. p.183.

${ }^{34}$ Irgit. Informant: a resident of Ust-Abakan District with. Uibat Republic of Khakassia G. Chebodaeva.

${ }^{35}$ Surunmaa SCH. Ethnonym Irgit: history and modernity in origin Mongun

Taygnskom kozhuun RT. Kyzyl: New research Tuvy. 2013;2.

${ }^{36}$ Tribe extremely warlike and rebellious (folkloric information about the legendary tribe Tumat Yakutia).

${ }^{37}$ Mongols. 2017.

${ }^{38}$ Surunmaa S.Ch. Ethnonym Irgit: history and modernity in origin Mongun Taygnskom kozhuun RT. Kyzyl: New research Tuvy. 2013;2.

${ }^{39}$ Surunmaa S.Ch. Ethnonym Irgit: history and modernity in origin Mongun

Taygnskom kozhuun RT. Kyzyl: New research Tuvy. 2013;2.

${ }^{40}$ Serdoba NA. The history of the Tuvan nation. Kyzyl. 1972. p.58. dynasty of China, Altai remained population group called itself Irkit and believes in local seok medium (native). ${ }^{41}$

Irgitas a kind of marked GN Potanin have kokchulutunov and Tuvan, who lived in Dzindzilike who called themselves tangnutuvasy. ${ }^{42}$

MA Castrén born irge (irgi) considered Samoyed. ${ }^{43}$ However, visiting Irkutsk in 1848, he said VV Radloff that some of Irgit living here speak a Turkic dialect, uses Karagas. ${ }^{44}$ The VV itself Radloff no hesitation in writing that "knee Irgit, byurut, choty and many othersthe Kyrgyz," that is Turkic. It is possible that WWRadloff based on message Klapreta, who visited the Tunka and established in 1805, that the language Soyots (Irgit) was Turkic. ${ }^{45}$

MF Katanov Irgit also applies to the Turks. ${ }^{46}$ SI Weinstein relates to Irgit Samodian origin groups that were Türkicized nip Samoyedic and Turk groups Altai- Sayansky plateau. Irgit involved (apart from the steppe tribes of Tuva) in Turkization samodiyskoyazychnyh Todzha tribes and perhaps some samodiysko- and Ket-speaking groups Minusinsk depression. ${ }^{47}$ Irgit tribal group as a whole in Tuva was divided into three kinds: Irgit, Kara Irgit and Saryg-Irgit. Ethnonym Irgit spread relatively widely. MA Castrén felt kind Irge (irgy) Samoyed. As previously mentioned in the letter, he said that between the Tunka Buryats steppe has immigrated generation Irkit; One part of this generation, who lived in the desert, it is Buryatified and the other lives in the mountains, spoke a Turkic dialect. ${ }^{48}$ By origin can be Uighur Uighur tribal Irgit group which is derived from ethnonim bayyrku consisting of two words: buy (rich) and yrku, ie rich yrku... According to MN Melheev, quoted MH Mannai-ool, "eventually magnify ethnonim element (buy Mannai-ool.) Dropped out, leaving only the actual yrku" with the addition of the Mongolian plural suffixut (-ud) um (-id) is form yrkuut (yrhud) Irkut (irhud) and Türkicized embodiment -irkit (Irgit). In this connection it is interesting to note that Tuvinian etnonim bei kara (black rich), rising to the same time, consists of two words. Turkologist WWRadloff not without reason to believe any kind of Irgit owned Yenisei Kyrgyz, or mixed with the Kyrgyz Uighur native. ${ }^{49}$

So we see that the ethnonym Irgit a close phonetic variants found in samodiyskoyazychnyh, Turkic-speaking and Mongolian groups. It is impossible not to draw attention to the very interesting fact. Tokarev expressed in connection with the question of the origin of the genus Irgen from coyotes proposal that Tuva is probably home

${ }^{41}$ Surunmaa S.Ch. Ethnonym Irgit: history and modernity in origin Mongun Taygnskom kozhuun RT. Kyzyl: New research Tuvy. 2013;2.

${ }^{42}$ Potanin GN. Essays on the north-western Mongolia [in four volumes]. St. Petersburg; 1893.

${ }^{43}$ Rassadin IV Formation Tofalar ethnic /I.V. Rassadin / Institute of Mongolian, Buddhist and Tibetan Studies of SB RAN.- Ulan-Ude, the Buryat Scientific Center of the Siberian Branch of the Russian Academy of Sciences, 2011. P. 114.

${ }^{44}$ Surunmaa SCH. Ethnonym Irgit: history and modernity in origin Mongun Taygnskom kozhuun RT. Kyzyl: New research Tuvy. 2013;2.

${ }^{45}$ Serdoba NA. The history of the Tuvan nation. Kyzyl. 1972. p.158.

${ }^{46}$ Ondar BK. NF Catania and Tuvan onomastika/Legacy Khakas scientist, Turkologist, Doctor of Comparative Linguistics, orientalist Nikolai Fedorovich Katanov: Proceedings of the International scientific conference devoted to the 150th anniversary of the birth of the scientist. 16-19 May 2012 Volume I. The - Abakan Khakassia Publishing House, 2012. 146 S. 112.

${ }^{47}$ Weinstein SI. Essay ethnogeny Tuvinians. UZTNIIYALI. (14):191.

${ }^{48}$ Ibid. p. 159

${ }^{49}$ Mannai-ool. MH Tuvinians: The origin and formation of the ethnic group. Novosibirsk. 2004. 67 p. 
to Irgit. Hence, one might conclude that Irgen composed kaybalov were samoedizirovannoy Turkic group. This, however, contradicts the observed pattern in Southern Siberia-samodiyskoyazychnye group is in contact with the Turkish-speaking lose their language, becoming a Turkic-speaking. Reverse the order of the phenomenon are not known. ${ }^{50}$ Irgit: They acted as intermediaries in the exchange trade between the Buryats and other Tuvan tribes. In 1660 at p. Irkut directed Cossack detachment collection iasak with drilled encountered a group Irgit Yandasha rulers (Yandash-darga). These Irgit asked to put near their nomadic jail, thus protecting them from the attacks of the Mongol princes. These Irgit paid tribute Russian. Since 1686 part of the Tuvan without the influence of the Mongol khans, began to flee to Mongolia. Later Tuvan hostages was not Tunka. ${ }^{51}$

All this confirms, firstly, the population of Tuva tribes very vast territory beyond the Sayan Mountains, secondly, takes place in the XVII century. process of tightening from the place of traditional nomadic and internal advancing certain tribal groups from the northeast to the west, south-western and south-eastern part of Tuva. However, much of it has remained outside. ${ }^{52}$

In the western part of Tuva lived a significant group Irgit, nomadic and that extends to the Southern Altai, for the separation of the border with Russia after the occupation of Tuva, the Manchu dynasty of China, as part of kokchulutanov remained population group called itself Irkit. Irgit group consisted of three khoshun: Oyunnarsky, Khemchiksky and Hasutsky. Irkit that were included Khemchiksky khoshun, where they constituted a separate sumon, lived along rivers Alash, Chad, Barlyk. In the middle of the twentieth century. Khemchiksky Irkit majority (over 270 people) lived in Mongun-Taiga. ${ }^{53}$

IU Sambuu writes in his paper that the native homeland Irgit is a modern area of Bai-Taiga kozhuun, terrain Dapsy, upper Alash. Hence, apparently, a number of reasons, they began to move it through the Mogen-Buren (Mongun-Tayginsky District) and the Mongolian Tuvan border further south, reaching Bayan-Ulgen, Sengela southeast through Erzin and Kosogol and move further up the river Irkut. ${ }^{54}$

There are many reasons to believe that the genus comes from the Altai Irgit Tuvan. Elderly people say that in the territory of Kara-Khol, Dapsy for centuries lived Kara Irgit. And today in the upper Hemchik are descendants Chedi Saryg-Irgit, in Mogen-Buren -potomki Kaksaan-Irgit. Altai Tuva were settled by the Mongolian Altai from the upper reaches of the river to the upper Kobdo Bulgan River in the valleys of the rivers Selenga, Sengel. The VI-II centuries they mixed with Altaians and their descendants further multiplied (Irgit). ${ }^{55}$

Describing the area populated by individual tribal groups Mongun-Tayginsky District, is particularly important to note one thing. Individual tribal groups live compactly, closely related, their encampments were located close to each other. For example, generic Kargy pastures of the valley of the river are home to small Salchak,

${ }^{50}$ Weinstein SI. Essay ethnogeny Tuvinians. Scientists TNIIYaLI note. 1957;(5):194-154.

${ }^{51}$ Weinstein SI. History Tuva. V 2 t - T. I. -2-eizd, Revised. and ext. Pod Society. Nauka; 2001; 367 p.

${ }^{52}$ Serdoba NA. The history of the Tuvan nation. Kyzyl. 1972. $162 \mathrm{p}$

${ }^{53}$ Potapov LP. Ethnography materials Tuvan districts Mongun-Taiga and Kara-Khol. Proceedings of Tuvan complex archaeological and ethnographic expedition. 1960.70 p.

${ }^{54}$ Samba IU. Ogbelerim breaker churtu, Onduri chaagay Mongun Taiga. Kyzyl; 1998.

${ }^{55}$ Surunmaa SCh. Ethnonym Irgit: history and modernity in origin Mongun Taygnskom kozhuun RT. Kyzyl: New research Tuvy. 2013(2).
Dongak, Khertek. Ancestral lands Kaksaan-Irgit are mostly located along the river Mogen-Buren, in the tributaries of the Aldi-Yymaaty. Winter camp (kyshtag) is located on the left bank of the river MogenBuren Charys area (a small tributary Mogen-Buren). The distance between the winter and spring camp is small. Spring camp is located in the town of Dyttyg-Aryg that on the left bank of the river. MogenBuren. Summer camp (Chaylag) located upriver Charys, Durug-Una (a small river, which rises out of the rocks), Saryg-Khovu ("watery area"), Kosh-Shynaa ("broad valley"). Autumn camp (kuzeg) often change periodically. Wander along the right bank Mogen-Buren in the town Kuzeg-Baary, Kadyrov Baary (upriver Charys), Kara Kuzhur. Spring camp (chazag) located in the area of Kyzyl-Eric Kara Kuzhur. Generic nomadic mugurskih Kaksaan-Irgit are mostly located on the left river valley Mugur. Winter roads are within places Destig-KaraSug; Chaylag Suglug -in-Khovu, Kara Yyash; Chazag -Olcheylig -Hovu; Kuzeg -Holchuktug-Khovu. At the mouth of the river Kargy live several Kara Irgit. Kyshtag them located in areas Oydaa-Odek. Chazag -within town Turug-Baary and Ulug-Shyk in the valley, on the right side of the river Kargy. Summer parking Kara Irgit located in Ak-Adyr, Kashpyy south of the village Mugur-Aksy. Autumn encampments were in the field of spring.

From Table 2 it can be noted that most reside in MogenBurenmskom sumone (236) and sumone Kargynskom (1585). The names of Irgit 1373 to 549 patronymic. So at the present time, according to the registrar, the number Irgit in kozhuun today is 1950 people., Which is much more than Salchak, Dongak, Khertek, Saaya, Oorzhak, Kara Salov. According alphabet books Kargynskogo sumona number Irgit in sumone Kargy is 1585 people. (4th place after Salchak, Dongak, Khertek); Currently, a group of tribal ritual conducted Irgit ovaa dagyyry in place "Kadir-Oruk" near lake Ak$\mathrm{Khol}^{56}$ Data prayer ovaa dagyyr held annually. So, a group of tribal Irgit is one of the largest groups. The whole tribal group Irgit in Tuva was divided into three kinds: Irgit, Kara Irgit and Saryg-Irgit. Thus, the tribal group Irgit was one of the first carrier name Tuva, "Tuva", as this ethnonym was first associated with the group Irgit, met Russian in the upper river. Irkut in the 60s. XVII century. And also, the tribe Irgit, along with Soyan, Tumat, Choodu and partly Maadi, Kuular was the distributor of the ethnonym Dubo, inclusive of the name "TuvaKizhi". ${ }^{57}$

\section{Tribal groups and dongak khertek}

Tuvan tribal group in the XIX and early XX century. In Tuva even more than ever were divided between newly created khoshuns and sumonami. Considering the list of tribal names, it should be noted that, according to this indicator, the tribal structure is characterized by mixed Tuvinians constituent ethnic elements, and above all the Turkic and Mongolian. The oldest ethnonims associated primarily with Turk Haganates period (VI-VIII cc.) Is "tele" (or carts), "Telenguts", "tolan" (Dolan) "Uighurs" "Kyrgyz". ${ }^{58}$ In the ancient period called the "body" was known to a large group of Turkic-speaking nomads who lived on the northern side of the Gobi desert and wandering through Mongolia and the Sayano-Altai mountains (including the Mongolian Altai). The tribes of the body, of course, were far from historical ancestors not only Tuvan tribal groups telly Telenguts,

${ }^{56}$ Informant Dongak Anai-Khaak Kyzyl-oolovna resident Mongun Taiga with. Mugur-Aksy, ul. Eric 24, was born with. Mugur-Aksy, born in 1974 profession of kindergarten teacher DOW "The Scarlet Flower".

${ }^{57}$ Ibid.

${ }^{58}$ LP Potapov. Tuvan folk life Essays. Novosibirsk: Publishing House "Nauka". Home Edition Oriental Literature. Moscow. 1969. 76 p. 
Tolan, but also modern Altai Teleuts telengits, Teleses. ${ }^{59}$ To this list phonetic version of the ethnonym "Teles" at that time to pay attention must be added and Tuvan in- Tyulyush (tulyush), which self is only a GEGrumm Grzhimailo.

Table I The names of Salchak found in 555 cases, in 140 cases, patronymic, and 24 names

\begin{tabular}{|c|c|c|c|c|}
\hline \multirow{2}{*}{$\begin{array}{l}\text { Sumony mongun } \\
\text { tayinskogo kozhuun }\end{array}$} & \multicolumn{3}{|l|}{ rural settlements } & \multirow[b]{2}{*}{ Total ethnicons } \\
\hline & Sumon kargynsky & Sumon mogen-burensky & Sumon toolaylyg & \\
\hline Population & 4270 & 1393 & 161 & 5824 \\
\hline Salchak & 156 & 443 & 120 & 719 \\
\hline $\begin{array}{l}\text { The number of } \\
\text { ethnonyms }\end{array}$ & The names of & The names & The patronymic & \\
\hline Salchak & 555 & 24 & 140 & 719 \\
\hline
\end{tabular}

Table 2 Data administration sumonov Mongun-Tayginsky District on $15.03 .2017 \mathrm{~g}$

\begin{tabular}{|c|c|c|c|c|}
\hline \multirow{2}{*}{$\begin{array}{l}\text { Sumony mongun- } \\
\text { tayginsky district }\end{array}$} & \multicolumn{4}{|l|}{ Rural settlements } \\
\hline & Sumon kargynsky & Sumon mogen-burensky & Sumon toolaylyg & Total ethnicons \\
\hline Population & 4270 & 1393 & 161 & 5824 \\
\hline Irgit & 1585 & 236 & 129 & 1950 \\
\hline \multicolumn{5}{|c|}{ The number of ethnonyms } \\
\hline \multirow[t]{2}{*}{ Irgit } & The names of & The names & The patronymic & \\
\hline & 1373 & 28 & 549 & 1950 \\
\hline
\end{tabular}

Table 3 Shows clearly that the tribal group Salchak is the largest, followed by Irgit, Dongak

\begin{tabular}{|c|c|c|c|c|}
\hline \multirow{2}{*}{$\begin{array}{l}\text { Sumony mongun tayinskogo } \\
\text { kozhuun }\end{array}$} & \multicolumn{3}{|l|}{ Rural settlements } & \multirow[b]{2}{*}{ Total ethnicons } \\
\hline & Sumon kargynsky & $\begin{array}{l}\text { Sumon mogen- } \\
\text { burensky }\end{array}$ & Sumon toolaylyg & \\
\hline Population & 4270 & 1393 & 161 & 5824 \\
\hline Salchak & 156 & 443 & 120 & 719 \\
\hline Irgit & 1585 & 236 & 129 & 1950 \\
\hline Dongak & 318 & 115 & 117 & 550 \\
\hline Khertek & 113 & 112 & 114 & 339 \\
\hline \multicolumn{5}{|l|}{ The number of ethnonyms } \\
\hline & The names of & The names & The patronymic & \\
\hline Irgit & 1373 & 28 & 549 & 1950 \\
\hline Salchak & 555 & 24 & 140 & 719 \\
\hline Dongak & 350 & 22 & 178 & 550 \\
\hline Khertek & 226 & - & 113 & 339 \\
\hline
\end{tabular}


A number of ethnonyms such as "Mongush", "Dongak", "Tumat", "Salchak", "Todzha" shows that in the formation of modern Tuvan attended by descendants of the medieval Turkic and Mongol tribes, related to the period of the Mongol Empire, which arose in beginning of XIII century. These ethnic names are well reflected in the wellknown Mongolian and Persian written sources. In the formation of the ethnic Tuvan participated Samoyed elements of ancient Aboriginal Sayano-Altai mountains, ethnic differences which have grown on the basis of the mountain taiga hunting, upland reindeer, gathering. ${ }^{61}$

So, inside and kozhuuns sumonov Tuvan population was also not uniform in tribal relations. However, this confusion was not the result of a natural process-when ethnic groups come into contact with each other without any coercion, voluntarily, due to a variety of specific reasons. Fragmentation and confusion of tribal groups emerged here as a result of the policy of the Chinese Manchu invaders, due to administrative measures. On the free mixing at the time could not be considered as Tuvan population, distributed by Pinsk authorities khoshuns sumonam and had no right of free movement and was fixed within a particular administrative unit. This circumstance can be explained by the fact. This prevented primarily Tuvinians attachment to various specific kozhuuns Princes (including many Mongolian), often warring. Let's start with Dongak group. Dongak group includes three sumonami in Beezi- khoshun under the names: Saryg-Dongak, Kara Dongak, chaat-Dongak (named district near Chaat Shagonar.). AP Ermolaev recorded three divisions Dongak: ak-Dongak, KaraDongak and Saryg Dongak. Kara Dongak of habitat also called Chadan-Dongak, although they lived and on the Alash, and Ishkin Saryg-Dongak roamed the rivers Barlyk, Ak and Chirgaky, sometimes with ak-Dongak. According to official stationery data, there were 103 Dongak yurt-car (on Yermolaev -55); Chaat-Dongak-324 tent (at no Yermolayeva full details) $)^{62}$ at the time of the study, LP Potapov in Mongun-Taiga there (151). The band is currently Dongak (Dongak), there are 550 people in the ethnonym, of them in sumone Kargynskom 318 people, Mogen-Burenskom 115 and sumone Toolaylyg 117. In most common surnames in Table 3.

Descent Dongak group carried rite ovaa near p. Kargy, ${ }^{63}$ The data also ovaa dagyyr prayers are held annually.

Khertek. Tuvan group called Khertek, the number sumonom in Beezi-khoshuns and inhabited the headwaters Hemchik. For clerical figures, there were 270 yurts and Materials AP Ermolaev-323 yurt. ${ }^{64}$

${ }^{59}$ History of Tuva. Novosibirsk, Science. 2001;309.

${ }^{60}$ Ibid. S. 309

${ }^{61}$ History of Tuva. Novosibirsk, 2001. - T. 1. - S. 309

${ }^{62}$ Dulov VI. Vestiges of the communal-tribal system. p. 63.

${ }^{63}$ Informant Dongak Anai-Khaak Kyzyl-oolovna resident Mongun Taiga with.

Mugur-Aksy, ul. Eric 24, was born with. Mugur-Aksy, born in 1974 profession of kindergarten teacher DOW "The Scarlet Flower" (Date: 04/02/2017).

${ }^{64}$ Lamin VA. History of Tuva $3 \mathrm{t}$-. T. II/Pod Society. Novosibirsk: Nauka; 2007. $179-180,430 \mathrm{p}$
Khertek marked GN Potanin in Salchakskom khoshuns in Hasutskom khoshuns the lake. Khubsugul (Kosogol) ${ }^{65}$ In Mongun-Taiga, there were 135, and in Kara-Khol village hall, 480 people. Tribal group Dongak little more than Khertek and basically they are also evenly distributed as Khertek. Ethnonym Dongak mainly found in surnames.

Descent Khertek group carried rite ovaa near p. Mugur, ${ }^{66}$ The data also ovaa dagyyr prayers are held annually. Thus, Table 3 shows clearly that the tribal group Salchak is the largest, followed by Irgit, Dongak.

\section{Results}

From the study it was found different versions of the origin of the genus Salchak, for example, scientists LV Grebnev, LP Potapov, GE Grum-Grzhimailo LR Kyzlasov et al. Believe Tuvan tribe descended from Mongolian Salchak saldzhiutov, and that is what the broken shards of Genghis Khan tribe saldzhiut. Khertek L. and A. Abaev tend to other versions, namely the origin of Salchaks chikami associated with that, it seems quite likely. Currently tribal group in Salchak Mongun-Tayginsky District live in sumone Kargynskom and MogunBurenskom. Irgit tribal group is among the largest groups. The whole tribal group Irgit in Tuva was divided into three kinds: Irgit, Kara Irgit and Saryg-Irgit. Rodoplemennnaya Irgit group was one of the first carrier Tuva name "Tuva", as this ethnonym was first associated with the group Irgit, met Russian in the upper river. Irkut in the 60s. XVII century. Also, Irgit, along with Soyan, Tumat, Choodu and partly Maadi, Kuular was the distributor of the ethnonym Dubo, inclusive of the name "Tuva-Kizhi". Tribal groups and Dongak Khertek compared with Salchak and Irgit in the minority. Thus, we have considered the above four tribal groups listed as contact to the natives MongunTaiga. They were compactly settled in certain areas and had close ties with each other. Apart from these, together with a number of them have lived and roamed some members of tribal groups such as the Khomushku, Mongush and partly Oorzhak and Saaya. But mostly it was the alien, or a few elements.

\section{Acknowledgments}

None.

\section{Funding}

Thanks, the study was sponsored by RFBR in the framework of a research project № 19-012-00073.

\section{Conflicts of interest}

Author declares that there is no conflict of interest.

\footnotetext{
${ }^{65}$ Dulov VI. Vestiges of the communal-tribal system. p. 63.

${ }^{6}$ Informant: Dongak Kyzyl-ool Doskaarovich, 1951g.r. 66 years old, resident of the village. Mugur-Aksy, Shepherd (Date: 04/05/2017).
} 